Article

\title{
Inhibitory Effect of Lactiplantibacillus plantarum and Lactococcus lactis Autochtonous Strains against Listeria monocytogenes in a Laboratory Cheese Model
}

\author{
Maria Barbara Pisano ${ }^{1,+}$ (D), Maria Elisabetta Fadda ${ }^{1,+}$, Silvia Viale ${ }^{1,+}{ }^{+}$, Maura Deplano ${ }^{1,+}$, Federica Mereu ${ }^{1,+}$, \\ Marijana Blažić ${ }^{2}$ and Sofia Cosentino ${ }^{1, *,+} \mathbb{D}$
}

Citation: Pisano, M.B.; Fadda, M.E.; Viale, S.; Deplano, M.; Mereu, F.; Blažić, M.; Cosentino, S. Inhibitory Effect of Lactiplantibacillus plantarum and Lactococcus lactis Autochtonous Strains against Listeria monocytogenes in a Laboratory Cheese Model. Foods 2022, 11, 715. https://doi.org/ 10.3390 /foods 11050715

Academic Editors: Luciana De Vero, Andrea Pulvirenti and

Ilaria Mannazzu

Received: 31 January 2022

Accepted: 25 February 2022

Published: 28 February 2022

Publisher's Note: MDPI stays neutral with regard to jurisdictional claims in published maps and institutional affiliations.

Copyright: (C) 2022 by the authors. Licensee MDPI, Basel, Switzerland. This article is an open access article distributed under the terms and conditions of the Creative Commons Attribution (CC BY) license (https:// creativecommons.org/licenses/by/ $4.0 /)$.
1 Department of Medical Sciences and Public Health, University of Cagliari, Cittadella Universitaria, SS 554, Km 4,500, 09042 Monserrato, Italy; barbara.pisano@unica.it (M.B.P.); mefadda@unica.it (M.E.F.); silviaviale@virgilio.it (S.V.); mdeplano@unica.it (M.D.); federica.mereu94@unica.it (F.M.)

2 Department of Food Technology, Karlovac University of Applied Sciences, Trg J.J.Strossmayera 9, 47000 Karlovac, Croatia; marijana.blazic@vuka.hr

* Correspondence: scosenti@unica.it; Tel.: +39-0706754146; Fax: +39-0706754197

+ Associated member of the JRU MIRRI-IT.

\begin{abstract}
In the present study, six Lactococcus lactis and seven Lactiplantibacillus plantarum strains isolated from artisanal Sardinian dairy products were evaluated for their efficacy in controlling the growth of Listeria monocytogenes during the storage of miniature fresh cheese manufactured on a laboratory scale to exploit their possible use as biopreservatives. The strains were tested for antimicrobial activity and some technological characteristics before using them in miniature fresh cheese to evaluate their in situ antilisterial effect. Our results showed that five strains (L. lactis 16FS169/20234-11FS16 and Lpb. plantarum 1/14537-4A/20045) could be considered suitable candidates for use as protective cultures in fresh cheese manufacture since they significantly lowered the pathogen counts by 3-4 log units compared to the control; however, all strains tested were capable of decreasing L. monocytogenes numbers. Our results suggest that the single and combined action of the acidifying power and the production of bacteriocin of these strains was capable of controlling and/or reducing the growth of L. monocytogenes. Considering their technological characteristics, they might be used as starter/adjunct cultures to increase the safety of the products, perhaps in association with other antimicrobial hurdles.
\end{abstract}

Keywords: antimicrobial; lactic acid bacteria (LAB); bacteriocin; biopreservation; Listeria monocytogenes

\section{Introduction}

The continuous attention of consumers versus natural and healthy food has led food research and industry to investigate the use of naturally occurring compounds (biopreservatives) in foods processing and preservation and to reduce the utilization of chemical additives as antimicrobials [1]. To this end, the use of lactic acid bacteria (LAB) has been described as an interesting approach for food biopreservation in alternative to chemicals and is also regarded by the consumer as a lower risk food preservation $[2,3]$.

LAB are widespread, occur naturally in many plants and animal food sources and have been safely used for a long time in the production of dairy and other fermented products, as attested by the attribution of QPS (Qualified Presumption of Safety, in EU) and GRAS (Generally Recognized as Safe, in the USA) status [4-7]. Today, LAB strains are widely used as starter/adjunct cultures in food production and provide the benefits of microbiological safety, uniformity, quality and durability in the final product [8-11]. In addition to heightening the technological and organoleptic properties of the final products, some strains have the ability to control the development of undesired or pathogenic microorganisms such as Listeria monocytogenes, Bacillus cereus, Staphylococcus aureus and 
Clostridium tyrobutyricum [12] and further improve food quality, safety and shelf-life [9]. In fact, the production of pathogen-inhibiting substances such as organic acids, hydrogen peroxide, $\mathrm{CO} 2$, diacetyl or antimicrobial peptides, i.e., bacteriocins, is a well-recognized ability in LAB [13-15]. These features have been demonstrated to be strain-dependent; therefore, studies reporting the screening of LAB of different origins with the purpose of discovering new probiotic or starter strains are rising by the day $[8,16]$.

Among LAB, the species Lactiplantibacillus plantarum (formerly known as Lactobacillus plantarum) and Lactococcus lactis are known to be naturally present in a variety of fermented food products, where they have been safely used for a long time [17,18].

$\mathrm{Lpb}$. plantarum is considered one of the most important species of lactobacilli because of its technological and probiotic characteristics. Various L pb. plantarum strains have been demonstrated to produce several antimicrobial agents against pathogenic or spoilage microorganisms. This antimicrobial impact has frequently been linked to the production of organic acids, such as lactic and phenyllactic acids [19-21].

Lactococcus lactis strains are the main LAB components of starter cultures used for the production of many fermented dairy products [22]. In cheese manufacture, the major characteristic of lactococci strains is their ability to quickly acidify milk, thus also contributing to the development of higher sensory properties (i.e., taste, flavor and texture) in cheeses [23]. Moreover, the occurrence of Lactococcus in cheeses has been linked with the increased microbial safety and stability of the products during storage, related to the production of substances (e.g., organic acids, bacteriocins, fat and amino-acid metabolites) capable of inhibiting spoilage and pathogenic microorganisms [13,24].

Foodborne diseases transmitted by dairy products still represent a significant safety issue in both developed and developing countries. Contamination can occur at any point in the supply chain and may arise from several sources (e.g., environmental, animal and human) [25]. It is therefore mandatory to control pathogens not only during milk production but also throughout cheese manufacturing. Cheese is, in fact, an efficient vehicle for foodborne pathogens, particularly fresh cheeses manufactured from raw milk. However, this contamination can also be present in cheese produced with pasteurized milk as a consequence of post-pasteurization contamination [26]. Due to the high $\mathrm{pH}$ and water activity combined with conservation at $4{ }^{\circ} \mathrm{C}$, fresh cheese warrants special consideration from a hygienic/safety point of view [27]. The microbial contamination of these products is crucial for the dairy industry due to economic losses and for public health because of the risk of transmitting pathogenic microorganisms, such as Listeria monocytogenes, to consumers. The major concern related to the occurrence of $L$. monocytogenes in foods is the possibility of developing listeriosis, one of the most severe foodborne diseases in developed countries [28]. Some characteristics of L. monocytogenes, such as its broad occurrence and ability to tolerate environmental stresses, including low $\mathrm{pH}$, low temperatures and salt concentration up to $10 \%[29,30]$, make it difficult to contain its presence in dairy foods. As a result, contaminated cheese has been involved in some of the major listeriosis outbreaks recorded in the world [27,31-33]. Soft-fresh cheeses are particularly vulnerable to contamination by L. monocytogenes because the processing and consumption of these products allow suitable conditions for its growth $[13,34,35]$. Controlling L. monocytogenes is crucial to food safety considering listeriosis' high mortality rate, especially among susceptible populations, such as pregnant women, newborns, the elderly and those with compromised immune systems [36].

The antilisterial activity of $L$. lactis strains is generally related to their ability to produce bacteriocins. In a previous study, we showed that six bacteriocin-producing L. lactis subsp. lactis strains isolated from artisanal Sardinian dairy products were able to inhibit L. monocytogenes during cocultivation in skimmed milk, decreasing the counts of approximately 4 log units compared to the positive control after $24 \mathrm{~h}$ of incubation [37].

Antibacterial activity, supposedly due to organic acid production by L $p b$. plantarum isolated from dairy products, has also been reported [3,38-40]. Recently, we have shown 
that the production of high levels of organic acids positively correlated with the antifungal activity in Lpb. plantarum strains [41].

In the present study, L. lactis and Lpb. plantarum strains isolated from artisanal Sardinian dairy products were evaluated for their efficacy in controlling the growth of L. monocytogenes during the storage of miniature fresh cheese manufactured at laboratory scale.

\section{Materials and Methods}

\subsection{Bacterial Strains and Culture Conditions}

Six Lactococcus lactis and 7 Lactiplantibacillus plantarum strains isolated from raw milk and artisanal ewe's cheeses were tested in the study. The strains were identified by phenotypic tests and genetic analysis based on polymerase chain reaction amplification using species-specific primers derived from $16 \mathrm{~S}$ rRNA sequences, as previously reported [42] and are deposited in the MicroBioDiverSar (MBDS) culture collection (www.mbds.it, accessed on $18 / 01 / 2022$ ). The strains were stored at $-20{ }^{\circ} \mathrm{C}$ in MRS broth (Microbiol, Cagliari, Italy) with $15 \%(w / v)$ glycerol and propagated three times in MRS broth for activation before experimental use. Listeria monocytogenes ATCC 7644, Escherichia coli ATCC 25922 and Staphylococcus aureus ATCC 25923, used as indicator strains in the antimicrobial activity assay, were stored on nutrient broth (NB, Microbiol) plus $20 \%(w / v)$ glycerol at $-20{ }^{\circ} \mathrm{C}$ and subcultured twice in the appropriate medium before use.

Of the 13 strains tested, 4 lactococci were characterized in previous studies as producers of antimicrobial substances and were also able to inhibit L. monocytogenes during cocultivation in skimmed milk [37,43-45], and 2 lactobacilli were shown to produce in vitro high levels of organic acids, particularly phenyllactic acid [41]. The remaining strains were included in this study because of their antimicrobial and technological features $[3,39,46,47]$. All strains were able to grow at $10^{\circ} \mathrm{C}$ (data not shown). The main characteristics of the strains used in this study have been outlined in Supplementary Table S1.

\subsection{Antimicrobial Activity Assay}

The LAB strains were screened for antimicrobial activity against the indicator strains reported above using the agar spot test method as described by Schillinger and Lücke [48]. Briefly, $3 \mu \mathrm{L}$ aliquots of a fresh overnight culture of the strains were spotted onto the surface of MRS agar $(1.2 \%(w / v)$ agar- $0.2 \%(w / v)$ glucose) plates. After incubation in a GasPak anaerobic jar (GENbox anaer, BioMeriéux, Marcy L'Etoile, France) for $24 \mathrm{~h}$ at $30^{\circ} \mathrm{C}$, the plates were overlaid with $7 \mathrm{~mL}$ soft agar medium (NB containing $0.7 \% w / v$ agar) seeded with the indicator strain to a final concentration of approximately $10^{7}$ colony-forming unit $(\mathrm{cfu}) / \mathrm{mL}$. After $24 \mathrm{~h}$ of incubation at the optimal growth temperature and atmosphere for the indicator strains, the presence of a detectable clear zone around the colony of the producer strain, which was considered indicative of inhibition, was measured.

\subsection{Technological Characteristics}

The caseinolytic activity was analyzed in plate count agar (PCA) (Microbiol) with $10 \%$ sterile reconstituted skim milk (RSM, Oxoid, Milan, Italy). After incubation at $30^{\circ} \mathrm{C}$ in aerobiosis, the presence of clear zones around the colony was verified. The lipolytic activity was determined on MRS (Microbiol) with $0.1 \%$ tributyrin. Lipolytic colonies were surrounded by clear zones against a turbid background of emulsified, unhydrolyzed lipids. Citrate utilization was observed as zones of clearing around colonies on calcium citrate medium [49]. The acidifying activity was assessed by inoculating $(1 \% w / v)$ the strains in RSM and incubating them for $24 \mathrm{~h}$ at $30^{\circ} \mathrm{C}$. The values of $\mathrm{pH}$ were measured using a HI8520 pH meter (Pool Bioanalysis Italiana, PBI, Milan, Italy) after 6 and $24 \mathrm{~h}$ of incubation. The acidifying activity was expressed as the decrease in $\mathrm{pH}$ with respect to the value of non-inoculated control milk, as previously reported [43]. All experiments were made in duplicate. 


\subsection{Preparation of the Inoculums}

Before manufacturing the cheese, each LAB strain was revitalized by incubation for $24 \mathrm{~h}$ at $30{ }^{\circ} \mathrm{C}$ in MRS broth. Individual colonies of each strain were transferred in RSM and incubated for $48 \mathrm{~h}$ at $30^{\circ} \mathrm{C}$ to achieve a final concentration of about $10^{7} \mathrm{cfu} / \mathrm{mL}$, which was confirmed with dilution and plating on MRS agar.

L. monocytogenes ATCC 7644 was seeded in NB and incubated for $18 \mathrm{~h}$ at $37^{\circ} \mathrm{C}$, then the revitalized cells were pelleted by centrifugation (Centrifuge 5804R, Eppendorf, Hamburg, Germany), for $10 \mathrm{~min}$ at $5900 \mathrm{~g}$, washed twice, resuspended in buffered peptone water and diluted to achieve the inoculum concentration of $10^{5} \mathrm{cfu} / \mathrm{mL}$, which was confirmed by enumeration on the selective medium Agar Listeria Ottaviani Agosti (ALOA, Microbiol).

\subsection{Miniature Fresh Cheese Manufacture and "In Situ" Antilisterial Activity of LAB}

Miniature fresh cheese was manufactured on a laboratory scale under aseptic conditions following the protocol reported in Supplementary Figure S1.

Pasteurized ewe's milk (6.4\% fat, $w / w)$ kindly provided by a local dairy farm (Argiolas Formaggi, Dolianova, CA, USA) cooled to $35-37^{\circ} \mathrm{C}$ was distributed in $500 \mathrm{~mL}$ aliquots in plastic containers and individually inoculated with each LAB strain (1\%) at a concentration of about $10^{7} \mathrm{cfu} / \mathrm{mL}$. L. monocytogenes $(1 \%)$ was added to the milk at a concentration of about $10^{5} \mathrm{cfu} / \mathrm{mL}$ immediately after LAB inoculation. After mixing gently with a sterile glass rod, commercial liquid rennet was added to ensure coagulation. After 10 to $15 \mathrm{~min}$ at $37^{\circ} \mathrm{C}$, the curd was cut into 4 blocks using a sterile knife, the excess whey was discarded, and the containers were stored at $10{ }^{\circ} \mathrm{C}$ and $85 \%$ humidity for up to 7 days. The weight of the cheeses was about $100 \mathrm{~g}$.

Miniature cheese manufacture was carried out on two different days, one for lactococci and one for lactobacilli strains, and two different kinds of cheese were made for each strain. In each experiment, control cheeses inoculated with L. monocytogenes only were included.

Cheeses were sampled in duplicate (two different kinds of cheese of each strain) for LAB and L. monocytogenes counts at the beginning (time 0 ) and at 1, 4 and 7 days of storage at $10^{\circ} \mathrm{C}$. Ten-gram aliquots of cheese were aseptically collected from each container, transferred to a sterile tube containing $90 \mathrm{~mL}$ of $2 \%(w / v)$ sodium-citrate sterile solution, homogenized in a Stomacher Lab Blender (PBI) for two minutes at normal speed, then serially diluted in sterile saline solution and plated onto MRS and ALOA agar plates for the enumeration of LAB and L. monocytogenes, respectively.

The $\mathrm{pH}$ value of the cheeses was determined using a HI8520 $\mathrm{pH}$ meter (PBI) at 1, 4 and 7 days of storage at $10{ }^{\circ} \mathrm{C}$ by homogenizing $10 \mathrm{~g}$ of cheese in $10 \mathrm{~mL}$ of distilled water.

\subsection{Statistical Analysis}

The results are depicted as mean with the standard deviation. Microbial counts were calculated as cfu per gram of sample and reported as $\log _{10} \mathrm{cfu} / \mathrm{g}$. The data derived from microbiological analyses were evaluated using one-way analysis of variance (ANOVA) and Bonferroni's multiple comparison test with GraphPad Prism Statistics software package version 5.00 (GraphPad Prism Software Inc., San Diego, CA, USA) in order to calculate the differences among the means. Significance was established at $p<0.05$. Correlations between L. monocytogenes growth in the different treatments and the $\mathrm{pH}$ were calculated using Pearson's correlation coefficient at 0.05 significant level.

\section{Results and Discussion}

Table 1 reports the evaluation of some technological activities in the LAB strains tested. 
Table 1. Technological characteristics of the autochthonous strains.

\begin{tabular}{|c|c|c|c|c|c|}
\hline \multirow{2}{*}{ Strains } & \multirow{2}{*}{ Casein Hydrolysis } & \multirow{2}{*}{ Lipolytic Activity $\S$} & \multirow{2}{*}{ Citrate Utilization } & \multicolumn{2}{|c|}{ Acidifying Activity * } \\
\hline & & & & $\Delta \mathrm{pH}(6 \mathrm{~h})$ & $\Delta \mathrm{pH}(24 \mathrm{~h})$ \\
\hline \multicolumn{6}{|c|}{ Lactococcus lactis } \\
\hline 16 FS16 & + & - & - & $0.91 \pm 0.05$ & $1.84 \pm 0.13$ \\
\hline 11 FS16 & - & - & + & $0.73 \pm 0.11$ & $1.22 \pm 0.10$ \\
\hline 6LS5 & + & - & - & $0.71 \pm 0.08$ & $1.44 \pm 0.07$ \\
\hline 1FS171M & + & - & - & $0.64 \pm 0.08$ & $1.24 \pm 0.15$ \\
\hline $2 \mathrm{~A} / \mathrm{SB}$ & + & - & - & $0.41 \pm 0.06$ & $1.90 \pm 0.03$ \\
\hline $9 / 20234$ & + & - & - & $0.57 \pm 0.09$ & $1.39 \pm 0.12$ \\
\hline \multicolumn{6}{|c|}{ Lactiplantibacillus plantarum } \\
\hline $62 \mathrm{LP} 39 \mathrm{~b}$ & + & - & + & $0.66 \pm 0.10$ & $1.14 \pm 0.14$ \\
\hline $11 / 20966$ & + & - & + & $0.67 \pm 0.09$ & $1.29 \pm 0.07$ \\
\hline $4 \mathrm{~A} / 20045$ & - & - & + & $0.50 \pm 0.11$ & $1.14 \pm 0.13$ \\
\hline $19 / 20711$ & + & - & + & $0.60 \pm 0.03$ & $1.08 \pm 0.12$ \\
\hline 1B3M & - & - & + & $0.63 \pm 0.12$ & $1.15 \pm 0.16$ \\
\hline $4 / 16898$ & + & - & + & $1.09 \pm 0.09$ & $2.22 \pm 0.11$ \\
\hline $1 / 14537$ & - & - & + & $1.02 \pm 0.05$ & $1.76 \pm 0.09$ \\
\hline
\end{tabular}

$\S$ on Tributyrin agar. ${ }^{*}$ Values presented are means \pm SD of two replicate evaluations for each strain.+ positive reaction, - negative reaction.

The majority of lactococci displayed proteolytic activity on casein agar after $24 \mathrm{~h}$ of incubation at $30{ }^{\circ} \mathrm{C}$. The ability to hydrolyze casein was found to be absent in some Lactiplantibacillus plantarum and in the Lactococcus lactis strain 11FS16. This property, widely described in LAB strains, in particular in L. lactis, is linked to the formation of free peptides and amino acids that can play a role in the development of aromas in cheeses. None of the strains demonstrated lipolytic activity on tributyrin agar. The citrate-fermenting activity, used as an indicator of the production of aromatic substances, was found to be present in all lactobacilli strains and in the L. lactis strain 11FS16 that was therefore assigned to biovar diacetylactis. In regards to the acidifying activity, a technological parameter of particular importance, the strains analyzed were generally medium acidifiers, determining a lowering of the $\mathrm{pH}$ of the milk higher than one unit after $24 \mathrm{~h}$ of incubation at $30{ }^{\circ} \mathrm{C}$, except for the strain Lpb. plantarum 4/16898, which caused a decrease in $\mathrm{pH}$ greater than 2 units. These results highlight a certain degree of variability in the technological characteristics examined not only between different species but also between strains belonging to the same species, indicating that these are properties mainly strain-related [50].

As shown in Table 2, most strains were able to antagonize Listeria monocytogenes, Staphylococcus aureus and Escherichia coli with clear inhibition zones of more than $4 \mathrm{~mm}$ in agar-spot plates. The lowest activity was detected against E. coli. A broad antagonistic activity of Lactobacillus towards different pathogenic microorganisms has been reported [51]; however, 27 strains of $L p b$. plantarum isolated from cheese showed no activity against selected indicator pathogens [52]. Several in vitro studies have demonstrated that the antagonistic activity of L. lactis cultures against pathogens, including L. monocytogenes, was generally related to the production of bacteriocins [53,54]. As reported in the literature, LAB are capable of producing several different substances with antimicrobial power, including the major metabolic end products such as organic acids, hydrogen peroxide, ethanol and bacteriocins [55].

When tested against L. monocytogenes ATCC 7644 with the well diffusion technique according to Schillinger \& Lücke [48], no residual antibacterial activity was observed in the Lpb. plantarum strains, while four strains of L. lactis exhibited inhibitory activity even after neutralization and catalase treatment of the supernatant, confirming their capability of producing antimicrobial compounds of proteinaceous nature, as shown in previous studies $[37,43]$ (data not shown). 
Table 2. Antibacterial activity of autochthonous strains determined by the agar spot test.

\begin{tabular}{|c|c|c|c|}
\hline Strains & S. aureus ATCC 25923 & E. coli ATCC 25922 & L. monocytogenes ATCC 7644 \\
\hline \multicolumn{4}{|c|}{ Lactococcus lactis } \\
\hline 16FS16 & + & - & + \\
\hline 11 FS16 & + & - & + \\
\hline 6LS5 & + & - & + \\
\hline 1FS171M & + & + & + \\
\hline $2 \mathrm{~A} / \mathrm{SB}$ & + & + & + \\
\hline $9 / 20234$ & + & - & + \\
\hline \multicolumn{4}{|c|}{ Lactiplantibacillus plantarum } \\
\hline 62LP39b & + & + & + \\
\hline $11 / 20966$ & + & + & + \\
\hline $4 \mathrm{~A} / 20045$ & + & + & + \\
\hline $19 / 20711$ & + & + & + \\
\hline 1B3M & + & + & + \\
\hline $4 / 16898$ & + & + & + \\
\hline $1 / 14537$ & + & + & + \\
\hline
\end{tabular}

+ positive reaction (inhibition zone $\geq 4 \mathrm{~mm}$ ). - negative reaction (inhibition zone $<4 \mathrm{~mm}$ ).

The effect of the LAB strains on the growth of L. monocytogenes ATCC 7644 in miniature cheeses produced under laboratory conditions, evaluated by one-way analysis of variance performed among the different treatments, is presented in Figure 1. Growth of L. monocytogenes in control samples increased from about $10^{5} \mathrm{cfu} / \mathrm{g}$ to $10^{7} \mathrm{cfu} / \mathrm{g}$ within $24 \mathrm{~h}$, reaching about $10^{9} \mathrm{cfu} / \mathrm{g}$ after 7 days of storage at $10^{\circ} \mathrm{C}$. In experimental cheeses, where L. monocytogenes was added together with the LAB strains, different trends in the growth were obtained and differences in the degree of inhibition were noted among the strains. In general, all LAB strains determined L. monocytogenes log reduction numbers with respect to the control ranging from 1.48 to 4.16 for lactococci and 1.96 to 4.21 for lactobacilli. Significantly lower $(p<0.05)$ Listeria counts were detected in cheeses produced with all LAB strains with respect to the control at 4 and 7 days of storage at $10{ }^{\circ} \mathrm{C}$. Three strains (L. lactis 16FS16 and Lpb. plantarum 1/14537 and 4A/20045) were able to significantly reduce $L$. monocytogenes counts by about $4 \mathrm{log}$ units compared to the control cheese and by $1.5 \log$ units compared to the initial inoculum at 7 days of storage at $10^{\circ} \mathrm{C}$. Other lactococci strains (9/20234, 11FS16 and 1FS171M) showed good bacteriostatic activity, with a reduction of more than $3 \log$ units compared to control. It is worth noting that the lactococci strains 11FS16, 9/20234 and 16FS16 were characterized in a previous study as producers of nisin A [43], but to the best of our knowledge, this is the first study reporting a strain of L. lactis biovar diacetylactis with inhibitory antilisterial potential in situ. The unexpectedly low antilisteria activity with L. lactis strain 6LS5, a nisin-Z producer [43], could indicate the presence of bacteriocin adsorption on the cell surface or on milk proteins or a low bacteriocin production in situ [56]. In the work by Dal Bello et al. [57], two L. lactis nisin-Zproducing strains also failed to inhibit L. monocytogenes in experimental cheese production, presumably because of the high inoculum $\left(10^{6} \mathrm{cfu} / \mathrm{mL}\right)$ of the pathogen. Similar results were also obtained by various authors who observed the failure of the antagonistic activity of bacteriocin in cheese compared to the results obtained in vitro [24,58]. It has also been shown that some factors related to cheese composition (fat content, proteolytic degradation, sodium chloride concentration) can affect the effectiveness of bacteriocins [59].

Cell counts of the LAB strains were also recorded during the storage of cheese at $10{ }^{\circ} \mathrm{C}$ (Supplementary Figure S2). All strains grew well in cheese samples, reaching counts around $10^{8}$ and $10^{9} \mathrm{cfu} / \mathrm{g}$ for lactococci and lactobacilli, respectively, after 7 days. 
A

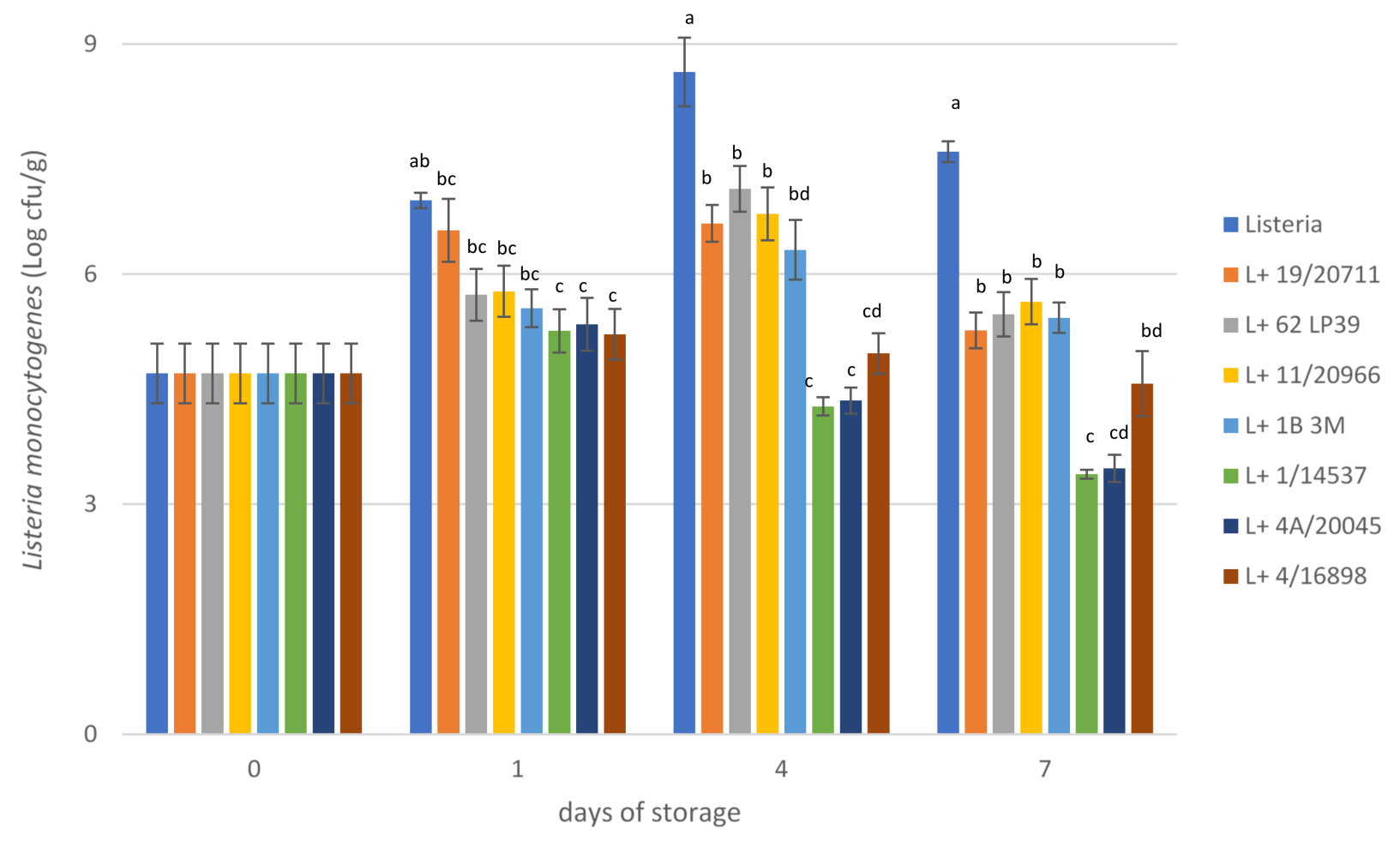

B 9

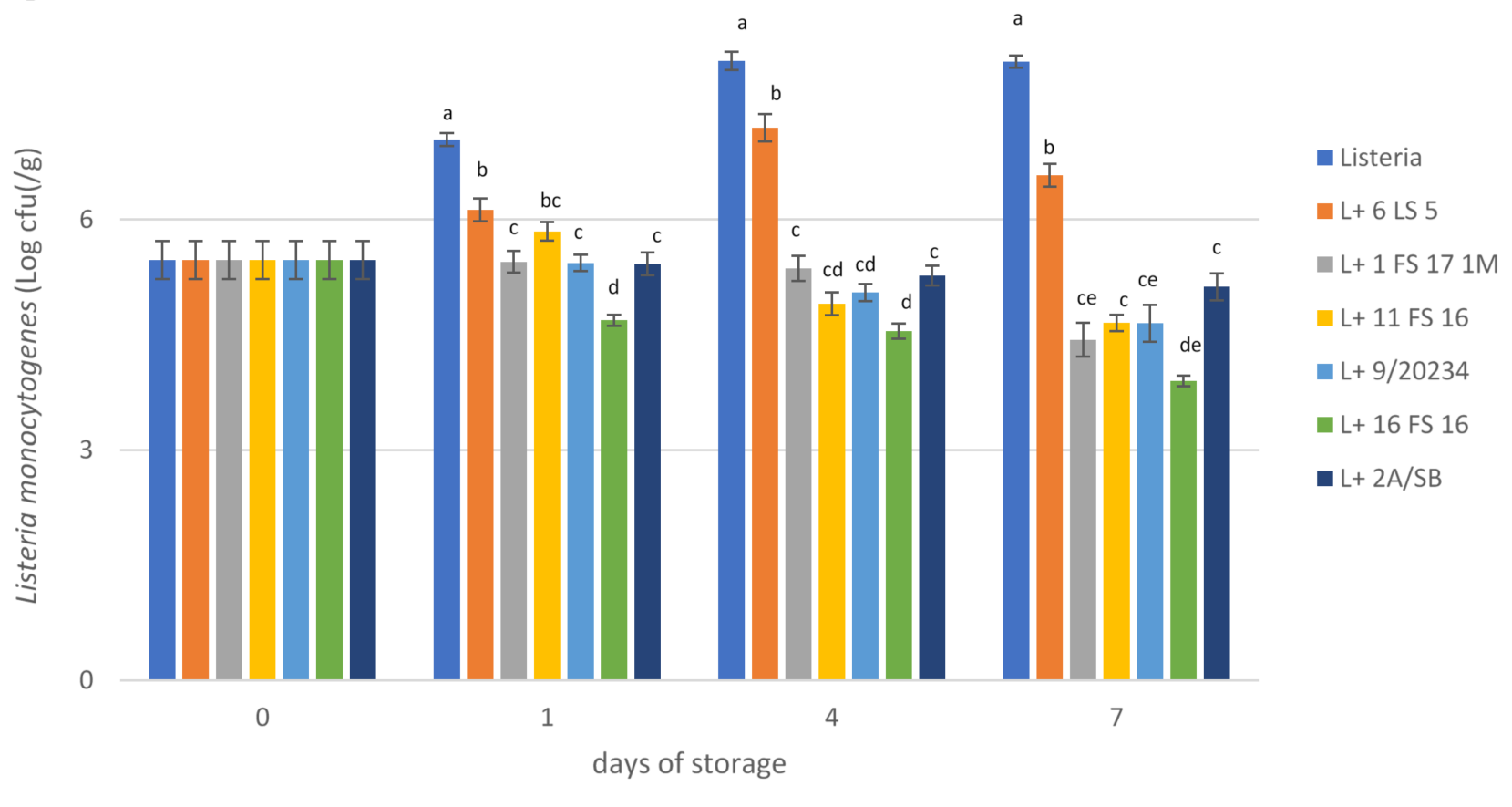

Figure 1. Effect of Lactiplantibacillus (A) and Lactococcus (B) strains on Listeria monocytogenes counts in experimental cheeses during storage $\left(1,4,7\right.$ days) at $10^{\circ} \mathrm{C}$ (means $\pm \mathrm{SD}$ of two samples). Means corresponding to the same storage time with different letters are significantly different $(p<0.05)$. 
Table 3 reports the evaluation of $\mathrm{pH}$ in control and experimental cheeses during storage. Values of $\mathrm{pH}$ generally decreased during storage and were reduced by approximately 2 units (1.5 to 2.5 units depending on the strain) at 7 days. The $\mathrm{pH}$ of cheeses was significantly influenced by both lactococci and lactobacilli strains during storage. A slight reduction in $\mathrm{pH}$ values during storage was also observed in control cheeses. Lactococci and lactobacilli are known to produce organic acids during cheese ripening, which are possibly accountable for the $\mathrm{pH}$ drop. It is known that the production of organic acid and decrease in $\mathrm{pH}$ values represent important factors in controlling the growth of L. monocytogenes [60]. In cheeses produced with lactococci strains 9/20234, 11FS16 and 16FS16 and with lactobacilli strains $1 / 14537$ and $4 \mathrm{~A} / 20045$, a significant correlation $(p<0.05)$ was observed between Listeria counts and $\mathrm{pH}$ values during storage. For the three lactococci strains, all nisinproducers, the antibacterial activity could be related to the combined production of both organic acids and antimicrobial metabolites, as already reported [61]. For the lactobacilli strains, the antilisterial activity could be ascribed to the production of organic acids, as we have recently shown in the case of strain 1/14537 [41]. In the work by Rogga et al. [34], the inactivation of L. monocytogenes in laboratory-scale Galotyri cheese was not related to the low $\mathrm{pH}$ of the cheeses produced with artisan-type inoculum because the cheeses produced with commercial strains supported the survival of the pathogen despite their even lower $\mathrm{pH}$. Conversely, other studies have pointed out a lower activity of nisin according to $\mathrm{pH}$ of cheese: Henderson et al. [62] showed that nisin is more effective when cheese is made at pH 6-6.5, and Samelis et al. [59] found that in situ antilisterial effects of nisin are limited in cheese with a low $\mathrm{pH}(5.5-5.8)$.

Table 3. $\mathrm{pH}$ of cheeses measured at 1,4 and 7 days of storage at $10{ }^{\circ} \mathrm{C}$ after inoculation with L. monocytogenes ATCC 7644 and each LAB strain (means \pm SD of two replicates for each sample).

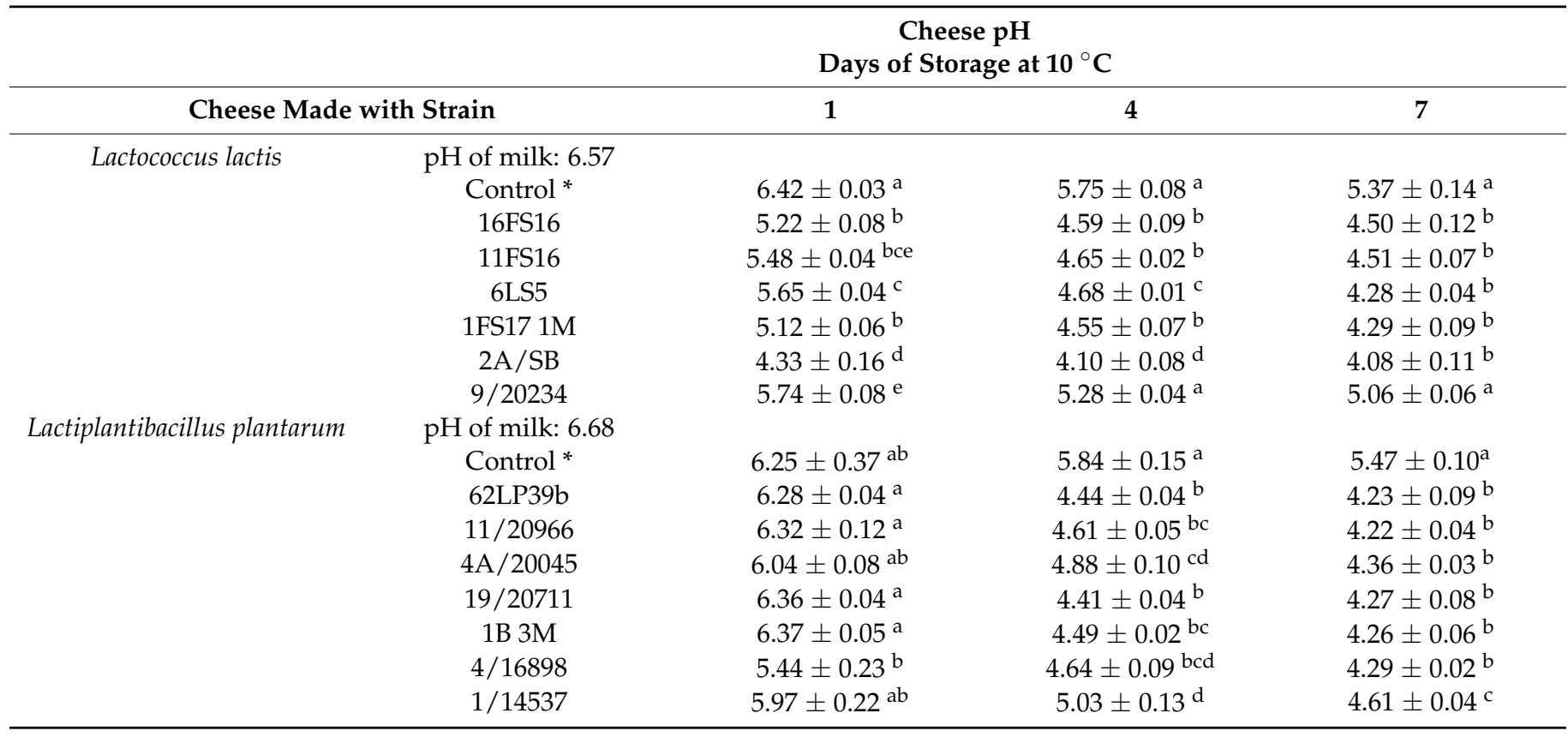

Means corresponding to the same storage time with different letters are significantly different $(p<0.05)$. ${ }^{*}$ Cheese inoculated with Listeria monocytogenes only.

Although in situ antilisterial activity of LAB strains has been evaluated in several studies, comparing the results is often difficult due to the different strains, type of antagonistic compounds, differences in cheese type, ripening period and storage temperature.

A reduction of 2-3 log units of Listeria counts in cheese were recorded after 7 days of ripening using bacteriocinogenic L. lactis [63]. In the study by Kondrotiene et al. [54], three nisin-producing L. lactis strains showed significantly reduced Listeria numbers by $2 \log$ units in fresh cheese during 7 days storage at $4{ }^{\circ} \mathrm{C}$. On the other hand, in the work by 
Samelis et al. [59], the application of a commercial starter culture with a nisin-A-producing L. lactis strain failed to determine a major (>3 to $5 \log$ units) in situ reduction in Listeria counts in Greek Graviera cheese due to weak or undetectable nisin activity. The addition of L. plantarum as an adjunct starter was successful in controlling L. monocytogenes during storage in ultra-filtered white cheese [64] and LAB, including two L. plantarum group strains, isolated from traditional cheeses produced in Calabria were effective both in vitro and in soft cheese in lowering Listeria counts from 0.5 to $1 \log \mathrm{cfu} / \mathrm{g}$ [65], while in Minas Frescal cheese, the L. plantarum ALC01 strain did not significantly affect listerial counts [66].

\section{Conclusions}

Among the microorganisms of technological interest, LAB are considered one of the most relevant microbial groups for their use as starter/adjunct cultures in the production of numerous fermented foods. In addition to conferring typical aromas and flavors, they exert an important protective effect, so the selection and use of indigenous lactic cultures to inhibit or reduce pathogens development and improve the quality of cheeses represents an alternative strategy to the various technological operations and thermal, physical, physicochemical and chemical treatments. The antimicrobial action of LAB may be expressed through the competition for nutritional elements and the production of metabolic compounds, including organic acids, bacteriocins and bacteriocin-like substances. In our study, five strains (L. lactis 16FS16-9/20234-11FS16 and Lpb. plantarum 1/14537-4A/20045) could be considered good candidates for use as protective cultures while manufacturing fresh cheese. Our results suggest that the single and combined action of the acidifying power and the production of bacteriocin in these strains was capable of controlling and/or reducing the growth of Listeria monocytogenes. Considering their technological characteristics, they could be used as starter/adjunct cultures to improve the safety of the products, perhaps in association with other antimicrobial hurdles, as suggested [58].

The results obtained at the laboratory scale are promising; however, further studies are needed on the evaluation of these strains according to safety criteria and on the determination of metabolites and antimicrobial compounds produced by the selected L. lactis and $L p b$. plantarum strains in order to evaluate their efficacy in controlling the growth of L. monocytogenes during cheese manufactured at factory scale.

Furthermore, these autochthonous strains, used as biopreservative agents, could represent a useful tool for the protection of the microbial biodiversity present in the Sardinian territory.

Supplementary Materials: The following supporting information can be downloaded at: https:/ / www.mdpi.com/article/10.3390/foods11050715/s1, Figure S1: Flow diagram of the cheese manufacturing procedure; Table S1: In vitro characteristics related to technological and antimicrobial properties of the microbial strains used in the study; Figure S2: title: Evolution of Lactococci (A) or Lactobacilli (B) counts in experimental cheeses during storage $\left(0,1,4,7\right.$ days) at $10^{\circ} \mathrm{C}$ (means $\pm \mathrm{SD}$ of two samples).

Author Contributions: Conceptualization, S.C. and M.B.P.; formal analysis and investigation, S.V., F.M., M.E.F. and M.D.; resources, M.E.F. and M.D.; writing-original draft preparation, S.C., M.B.P., S.V., F.M., M.E.F., M.D. and M.B.; Software, M.B.P. and M.B.; data curation, M.B.P., S.V. and M.B.; writing-review and editing, M.B.P., S.V., M.B. and S.C.; supervision, S.C.; project administration, S.C.; funding acquisition, S.C., M.B.P. and M.B. All authors have read and agreed to the published version of the manuscript.

Funding: This paper was produced as part of the "Atrium of Knowledge" project co-financed by the European Union from the European Regional Development Fund and the Operational Programme Competitiveness and Cohesion 2014-2020. Contract No: KK.01.1.1.02.0005. It was also partially supported by grants from Università di Cagliari (Progetti FIR, 2018).

Institutional Review Board Statement: Not applicable.

Informed Consent Statement: Not applicable. 
Data Availability Statement: The mean \pm standard deviation of microbial data used to support the findings of this study are included in the article. The raw data are available on reasonable request from the corresponding author.

Acknowledgments: The authors thank Argiolas Formaggi (Dolianova, Cagliari) for kindly providing milk and for technical assistance.

Conflicts of Interest: The authors declare no conflict of interest.

\section{References}

1. Paul Ross, R.; Morgan, S.; Hill, C. Preservation and fermentation: Past, present and future. Int. J. Food Microbiol. 2002, 79, 3-16. [CrossRef]

2. Ibrahim, S.A.; Ayivi, R.D.; Zimmerman, D.; Siddiqui, S.A.; Altemimi, A.B.; Fidan, H.; Esatbeyoglu, T.; Bakhshayesh, R.V. Lactic acid bacteria as antimicrobial agents: Food safety and microbial food spoilage prevention. Foods 2021, 10, 3131. [CrossRef]

3. Cosentino, S.; Viale, S.; Deplano, M.; Fadda, M.E.; Pisano, M.B. Application of autochthonous Lactobacillus strains as biopreservatives to control fungal spoilage in caciotta cheese. Hindawi BioMed Res. Int. 2018, 2018, 3915615. [CrossRef] [PubMed]

4. European Food Safety Authority. Statement on the update of the list of QPS-recommended biological agents intentionally added to food or feed as notified to EFSA. 2: Suitability of taxonomic units notified to EFSA until March 2015. EFSA J. 2015, 13, 4138.

5. National Research Council 1978. 1975 Resurvey of the Annual Poundage of Food Chemicals Generally Recognized as Safe (GRAS); National Academies Press: Washington, DC, USA, 1978.

6. Hurtado, A.; Reguant, C.; Bordons, A.; Rozès, N. Lactic acid bacteria from fermented table olives. Food Microbiol. 2012, 31, 1-8 [CrossRef] [PubMed]

7. Grosu-Tudor, S.S.; Stancu, M.M.; Pelinescu, D.; Zamfir, M. Characterization of some bacteriocins produced by lactic acid bacteria isolated from fermented foods. World J. Microbiol. Biotechnol. 2014, 30, 2459-2469. [CrossRef]

8. Rezpkowska, A.; Zielińska, D.; Ołdak, A.; Kołożyn-Krajewska, D. Organic whey as a source of Lactobacillus strains with selected technological and antimicrobial properties. Int. J. Food Sci. Technol. 2017, 52, 1983-1994. [CrossRef]

9. Favaro, L.; Penna, A.L.B.; Todorov, S.D. Bacteriocinogenic LAB from cheeses-Application in biopreservation? Trends Food Sci. Technol. 2015, 41, 37-48. [CrossRef]

10. Blana, V.A.; Grounta, A.; Tassou, C.C.; Nychas, G.-J.E.; Panagou, E.Z. Inoculated fermentation of green olives with potential probiotic Lactobacillus pentosus and Lactobacillus plantarum starter cultures isolated from industrially fermented olives. Food Microbiol. 2014, 38, 208-218. [CrossRef]

11. Nieto-Arribas, P.; Poveda, J.M.; Seseña, S.; Palop, L.; Cabezas, L. Technological characterization of Lactobacillus isolates from traditional Manchego cheese for potential use as adjunct starter cultures. Food Control 2009, 20, 1092-1098. [CrossRef]

12. Gálvez, A.; López, R.L.; Abriouel, H.; Valdivia, E.; Omar, N.B. Application of bacteriocins in the control of food borne pathogenic and spoilage bacteria. Crit. Rev. Biotechnol. 2008, 28, 125-152. [CrossRef]

13. Coelho, M.C.; Silva, C.C.G.; Ribeiro, S.C.; Dapkevicius, M.L.N.E.; Rosa, H.J.D. Control of Listeria monocytogenes in fresh cheese using protective lactic acid bacteria. Food Microbiol. 2014, 191, 53-59. [CrossRef]

14. Gonzáles, L.; Sandoval, H.; Sacristán, N.; Castro, J.; Fresno, J.; Tornadijo, M. Identification of lactic acid bacteria isolated from Genestoso cheese throughout ripening and study of their antimicrobial activity. Food Control 2007, 18, 716-722. [CrossRef]

15. Stiles, M.E.; Holzapfel, W.H. Lactic acid bacteria of foods and their current taxonomy. Int. J. Food Microbiol. 1997, 36, 1-29. [CrossRef]

16. Barbosa, J.; Borges, S.; Teixeira, P. Pediococcus acidilactici as a potential probiotic to be used in food industry. Int. J. Food Sci. Technol. 2015, 50, 1151-1157. [CrossRef]

17. Valenzuela, J.F.; Pinuer, L.A.; Cancino, A.G.; Yáñez, R.B. Metabolic fluxes in Lactic acid bacteria-A review. Food Biotechnol. 2015, 29, 185-217. [CrossRef]

18. Siezen, R.J.; Tzeneva, V.A.; Castioni, A.; Wels, M.W.W.; Phan, H.T.; Rademaker, J.L.W.; Starrenburg, M.J.C.; Kleerebezem, M.; Molenaar, D.; van Hylckama Vlieg, J.E.T. Phenotypic and genomic diversity of Lactobacillus plantarum strains isolated from various environmental niches. Environ. Microbiol. 2010, 12, 758-773. [CrossRef] [PubMed]

19. Guidone, A.; Zotta, T.; Ross, R.P.; Stanton, C.; Rea, M.C.; Parente, E.; Ricciardi, A. Functional properties of Lactobacillus plantarum strains: A multivariate screening study. LWT Food Sci. Technol. 2014, 56, 69-76. [CrossRef]

20. Rodríguez-Pazo, N.; Vázquez-Araújo, L.; Pérez-Rodríguez, N.; Cortés-Diéguez, S.; Domínguez, J.M. Cell-free supernatants obtained from fermentation of cheese whey hydrolyzates and phenylpyruvic acid by Lactobacillus plantarum as a source of antimicrobial compounds, bacteriocins, and natural aromas. Appl. Biochem. Biotechnol. 2013, 171, 1042-1060. [CrossRef]

21. Neal-McKinney, J.M.; Lu, X.; Duong, T.; Larson, C.L.; Call, D.R.; Shah, D.H.; Konkel, M.E. Production of organic acids by probiotic Lactobacilli can be used to reduce pathogen load in poultry. PLoS ONE 2012, 7, e43928. [CrossRef]

22. Ho, V.T.T.; Lo, R.; Bansal, N.; Turner, M.S. Characterisation of Lactococcus lactis isolates from herbs, fruits and vegetables for use as biopreservatives against Listeria monocytogenes in cheese. Food Control 2018, 85, 472-483. [CrossRef]

23. López-Díaz, T.M.; Alonso, C.; Román, C.; García-López, M.L.; Moreno, B. Lactic acid isolates from a hand-made blue cheese. Food Microbiol. 2000, 17, 23-32. [CrossRef] 
24. Dal Bello, B.; Cocolin, L.; Zeppa, G.; Field, D.; Cotter, P.D.; Hill, C. Technological characterization of bacteriocin producing Lactococcus lactis strains employed to control Listeria monocytogenes in Cottage cheese. Int. J. Food Microbiol. 2012, 153, 58-65. [CrossRef]

25. Hanning, I.B.; O’Bryan, C.A.; Crandall, P.G.; Ricke, S.C. Food safety and food security. Nat. Educ. Knowl. $2012,3,9$.

26. Brooks, J.C.; Martinez, B.; Stratton, J.; Bianchini, A.; Krokstrom, R.; Hutkins, R. Survey of raw milk cheeses for microbiological quality and prevalence of foodborne pathogens. Food Microbiol. 2012, 31, 154-158. [CrossRef]

27. De Castro, V.; Escudero, J.M.; Rodriguez, J.L.; Muniozguren, N.; Uribarri, J.; Saez, D.; Vazquez, J. Listeriosis outbreak caused by Latin-style fresh cheese, Bizkaia, Spain. Eurosurveillance 2012, 17, 8-10. [CrossRef]

28. Schlech, W.F., III; Acheson, D. Foodborne listeriosis. Clin. Infect. Dis. 2000, 31, 770-775. [CrossRef]

29. Gandhi, M.; Chikindas, M.L. Listeria: A foodborne pathogen that knows how to survive. Int. J. Food Microbiol. 2007, 113, 1-15. [CrossRef] [PubMed]

30. Cole, M.B.; Jones, M.V.; Holyoak, C. The effect of $\mathrm{pH}$, salt concentration and temperature on the survival and growth of Listeria monocytogenes. J. Appl. Bacteriol. 1990, 69, 63-72. [CrossRef]

31. McIntyre, L.; Wilcott, L.; Naus, M. Listeriosis outbreaks in British Columbia, Canada, caused by soft ripened cheese contaminated from environmental sources. BioMed Res. Int. 2015, 2015, 131623. [CrossRef] [PubMed]

32. Koch, J.; Dworak, R.; Prager, R.; Becker, B.; Brockmann, S.; Wicke, A.; Wichmann-Schauer, H.; Hof, H.; Werber, D.; Stark, K. Large listeriosis outbreak linked to cheese made from pasteurized milk, Germany, 2006-2007. Foodborne Pathog. Dis. 2010, 7, 1581-1584. [CrossRef] [PubMed]

33. Makino, S.-I.; Kawamoto, K.; Takeshi, K.; Okada, Y.; Yamasaki, M.; Yamamoto, S.; Igimi, S. An outbreak of food-borne listeriosis due to cheese in Japan, during 2001. Int. J. Food Microbiol. 2005, 104, 189-196. [CrossRef]

34. Rogga, K.J.; Samelis, J.; Kakouri, A.; Katsiari, M.C.; Savvaidis, I.N.; Kontominas, M.G. Survival of Listeria monocytogenes in Galotyri, a traditional Greek soft acid-curd cheese, stored aerobically at $4{ }^{\circ} \mathrm{C}$ and $12{ }^{\circ} \mathrm{C}$. Int. Dairy J. 2005, 15, 59-67. [CrossRef]

35. Kabuki, D.Y.; Kuaye, A.Y.; Wiedmann, M.; Boor, K.J. Molecular subtyping and tracking of Listeria monocytogenes in Latin-style fresh-cheese processing plants. J. Dairy Sci. 2004, 87, 2803-2812. [CrossRef]

36. Jackson, K.A.; Gould, L.H.; Hunter, J.C.; Kucerova, Z.; Jackson, B. Listeriosis outbreaks associated with soft cheeses, United States, 1998-2014. Emerg. Infect. Dis. 2018, 24, 1116-1118. [CrossRef]

37. Cosentino, S.; Fadda, M.E.; Deplano, M.; Melis, R.; Pomata, R.; Pisano, M.B. Antilisterial activity of nisin-like bacteriocin producing Lactococcus lactis subsp. lactis isolated from traditional sardinian dairy products. J. Biomed. Biotechnol. 2012, $2012,376428$.

38. Ołdak, A.; Zielińska, D.; Rzepkowska, A.; Kołożyn-Krajewska, D. Comparison of antibacterial activity of Lactobacillus plantarum strains isolated from two different kinds of regional cheeses from Poland: Oscypek and korycinski cheese. BioMed Res. Int. 2017, 2017, 6820369. [CrossRef]

39. Pisano, M.B.; Viale, S.; Conti, S.; Fadda, M.E.; Deplano, M.; Melis, M.P.; Deiana, M.; Cosentino, S. Preliminary evaluation of probiotic properties of Lactobacillus strains isolated from Sardinian dairy products. BioMed Res. Int. 2014, 2014, 286390. [CrossRef]

40. Pisano, M.B.; Patrignani, F.; Cosentino, S.; Guerzoni, M.E.; Franz, C.M.A.P.; Holzapfel, W.H. Diversity and functional properties of Lactobacillus plantarum-group strains isolated from Italian cheese products. Dairy Sci. Technol. 2010, 91, 65-76.

41. Scano, P.; Pisano, M.B.; Murgia, A.; Cosentino, S.; Caboni, P. GC-MS metabolomics and antifungal characteristics of autochthonous Lactobacillus strains. Dairy 2021, 2, 326-335. [CrossRef]

42. Pisano, M.B.; Fadda, M.E.; Deplano, M.; Corda, A.; Cosentino, S. Microbiological and chemical characterization of Fiore Sardo, a traditional Sardinian cheese made from ewe's milk. Int. J. Dairy Technol. 2006, 59, 171-179. [CrossRef]

43. Pisano, M.B.; Fadda, M.E.; Melis, R.; Ciusa, M.L.; Viale, S.; Deplano, M.; Cosentino, S. Molecular identification of bacteriocins produced by Lactococcus lactis dairy strains and their technological and genotypic characterization. Food Control 2015, 51, 1-8. [CrossRef]

44. Siroli, L.; Camprini, L.; Pisano, M.B.; Patrignani, F.; Lanciotti, R. Volatile molecule profiles and anti-Listeria monocytogenes activity of nisin producers Lactococcus lactis strains in vegetable drinks. Front. Microbiol. 2019, 10, 563. [CrossRef] [PubMed]

45. Bukvicki, D.; Siroli, L.; D’Alessandro, M.; Cosentino, S.; Fliss, I.; Said, L.B.; Hassan, H.; Lanciotti, R.; Patrignani, F. Unravelling the potential of Lactococcus lactis strains to be used in cheesemaking production as biocontrol agents. Foods 2020, 9, 1815. [CrossRef] [PubMed]

46. Cosentino, S.; Pisano, B.; Piras, C.; Deplano, M.; Palmas, F. Chatacterization of lactic acid bacteria isolated from traditional Fiore Sardo cheese. In Proceedings of the International Conference SFAM, Wageningen, The Netherlands, 9-11 January 2002; pp. 104-107.

47. Pisano, M.B.; Casula, M.; Corda, A.; Fadda, M.E.; Deplano, M.; Cosentino, S. In vitro probiotic characteristics of Lactobacillus strains isolated from Fiore Sardo cheese. Ital. J. Food Sci. 2008, 20, 505-516.

48. Schillinger, U.; Lücke, F.K. Antibacterial activity of Lactobacillus sake isolated from meat. Appl. Environ. Microbiol. 1989, 55, 1901-1906. [CrossRef]

49. Galeslod, T.E.; Hassing, F.; Stadhouders, J. Agar medium for the isolation and enumeration of aroma bacteria in starters. Neth Milk Dairy J. 1961, 15, 127-129.

50. Perez, G.; Cardell, E.; Zarate, V. Technological characterization of lactic acid bacteria from Tenerife cheese. Int. J. Food Sci. Technol. 2003, 38, 537-546. [CrossRef] 
51. Georgieva, R.N.; Iliev, I.N.; Chipeva, V.A.; Dimitonova, S.P.; Samelis, J.; Danova, S.T. Identification and in vitro characterization of Lactobacillus plantarum strains from artisanal Bulgarian white brined cheeses. J. Basic Microbiol. 2008, 48, 234-244. [CrossRef]

52. Zago, M.; Fornasari, M.E.; Carminati, D.; Burns, P.; Suàrez, V.; Vinderola, G.; Reinheimer, J.; Giraffa, G. Characterization and probiotic potential of Lactobacillus plantarum strains isolated from cheeses. Food Microbiol. 2011, 28, 1033-1040. [CrossRef]

53. Nero, L.A.; Mattos, M.R.; Beloti, V.; Barros, M.A.F.; Ortolani, M.B.T.; Franco, B.D.G.M. Autochthonous microbiota of raw milk with antagonistic activity against Listeria monocytogenes and Salmonella enteritidis. J. Food Saf. 2009, 29, 261-270. [CrossRef]

54. Kondrotiene, K.; Kasnauskyte, N.; Serniene, L.; Gölz, G.; Alter, T.; Kaskoniene, V.; Maruska, A.S.; Malakauskas, M. Characterization and application of newly isolated nisin producing Lactococcus lactis strains for control of Listeria monocytogenes growth in fresh cheese. LWT-Food Sci. Technol. 2018, 87, 507-514. [CrossRef]

55. Servin, A.L. Antagonistic activities of lactobacilli and bifidobacterial against microbial pathogens. FEMS Microbiol. Rev. 2004, 28, 405-440. [CrossRef] [PubMed]

56. Falardeau, J.; Trmčić, A.; Wang, S. The occurrence, growth, and biocontrol of Listeria monocytogenes in fresh and surface-ripened soft and semisoft cheeses. Compr. Rev. Food Sci. Food Saf. 2021, 20, 4019-4048. [CrossRef] [PubMed]

57. Dal Bello, B.; Zeppa, G.; Bianchi, D.M.; Decastelli, L.; Traversa, A.; Gallina, S.; Coisson, J.D.; Locatelli, M.; Travaglia, F.; Cocolin, L. Effect of nisin-producing Lactococcus lactis starter cultures on the inhibition of two pathogens in ripened cheeses. Int. J. Dairy Technol. 2013, 66, 468-477.

58. Furtado, D.N.; Todorov, S.D.; Landgraf, M.; Destro, M.T.; Franco, B.D.G.M. Bacteriocinogenic Lactococcus lactis subsp. lactis DF04Mi isolated from goat milk: Application in the control of Listeria monocytogenes in fresh Minas-type goat cheese. Braz. J. Microbiol. 2015, 46, 201-206.

59. Samelis, J.; Giannou, E.; Pappa, E.C.; Bogović-Matijašić, B.; Lianou, A.; Parapouli, M.; Drainas, C. Behavior of artificial listerial contamination in model Greek Graviera cheeses manufactured with the indigenous nisin A-producing strain Lactococcus lactis subsp. cremoris M104 as costarter culture. J. Food Saf. 2017, 37, e12326.

60. Martinez-Rios, V.; Gkogka, E.; Dalgaard, P. New term to quantify the effect of temperature on pHmin-values used in cardinal parameter growth models for Listeria monocytogenes. Front. Microbiol. 2019, 10, 1510. [CrossRef]

61. Campagnollo, F.B.; Margalho, L.P.; Kamimura, B.A.; Feliciano, M.D.; Freire, L.; Lopes, L.S.; Alvarenga, V.O.; Cadavez, V.A.P.; Gonzales-Barron, U.; Schaffner, D.W.; et al. Selection of indigenous lactic acid bacteria presenting anti-listerial activity, and their role in reducing the maturation period and assuring the safety of traditional Brazilian cheeses. Food Microbiol. 2018, 73, 288-297. [CrossRef]

62. Henderson, L.O.; Erazo Flores, B.J.; Skeens, J.; Kent, D.; Murphy, S.I.; Wiedmann, M.; Guariglia-Oropeza, V. Nevertheless, she resisted-Role of the environment on Listeria monocytogenes sensitivity to nisin treatment in a laboratory cheese model. Front. Microbiol. 2020, 11, 635. [CrossRef]

63. Rodríguez, E.; Calzada, J.; Arqués, J.L.; Rodríguez, J.M.; Nuñez, M.; Medina, M. Antimicrobial activity of pediocin-producing Lactococcus lactis on Listeria monocytogenes, Staphylococcus aureus and Escherichia coli O157:H7 in cheese. Int. Dairy J. 2005, $15,51-57$. [CrossRef]

64. Ahmadzadeh Nia, S.; Hanifian, S. Survival of Listeria monocytogenes strains in ultra-filtered white cheese: Effect of Lactobacillus plantarum and incubation period. J. Food Process. Preserv. 2017, 41, e13283. [CrossRef]

65. Panebianco, F.; Giarratana, F.; Caridi, A.; Sidari, R.; De Bruno, A.; Giuffrida, A. Lactic acid bacteria isolated from traditional Italian dairy products: Activity against Listeria monocytogenes and modelling of microbial competition in soft cheese. LWT-Food Sci. Technol. 2021, 137, 110446. [CrossRef]

66. Nascimento, M.S.; Moreno, I.; Kuaye, A.Y. Applicability of bacteriocin-producing Lactobacillus plantarum, Enterococcus faecium and Lactococcus lactis ssp. lactis as adjunct starter in Minas Frescal cheesemaking. Int. J. Dairy Technol. 2008, 61, 352-357. 